\title{
High variability of HIV and HCV seroprevalence and risk behaviours among people who inject drugs: results from a cross-sectional study using respondent-driven sampling in eight German cities (2011-14)
}

Benjamin Wenz ${ }^{1}$, Stine Nielsen ${ }^{1,2}$, Martyna Gassowski ${ }^{1}$, Claudia Santos-Hövener ${ }^{1}$, Wei Cai ${ }^{1}$, R. Stefan Ross ${ }^{3}$, Claus-Thomas Bock ${ }^{4}$, Boris-Alexander Ratsch ${ }^{4}$, Claudia Kücherer ${ }^{5}$, Norbert Bannert ${ }^{5}$, Viviane Bremer ${ }^{1}$, Osamah Hamouda ${ }^{1}$, Ulrich Marcus ${ }^{1}$, Ruth Zimmermann ${ }^{1 *}$ and the DRUCK Study group

\begin{abstract}
Background: People who inject drugs (PWID) are at increased risk of acquiring and transmitting HIV and Hepatitis $\mathrm{C}(\mathrm{HCV})$ due to sharing injection paraphernalia and unprotected sex. To generate seroprevalence data on HIV and HCV among PWID and related data on risk behaviour, a multicentre sero- and behavioural survey using respondent driven sampling (RDS) was conducted in eight German cities between 2011 and 2014. We also evaluated the feasibility and effectiveness of RDS for recruiting PWID in the study cities.

Methods: Eligible for participation were people who had injected drugs within the last 12 months, were 16 years or older, and who consumed in one of the study cities. Participants were recruited, using low-threshold drop-in facilities as study sites. Initial seeds were selected to represent various sub-groups of people who inject drugs (PWID). Participants completed a face-to-face interview with a structured questionnaire about socio-demographics, sexual and injecting risk behaviours, as well as the utilisation of health services. Capillary blood samples were collected as dried blood spots and were anonymously tested for serological and molecular markers of HIV and HCV. The results are shown as range of proportions (min. and max. values (\%)) in the respective study cities. For evaluation of the sampling method we applied criteria from the STROBE guidelines.

(Continued on next page)
\end{abstract}

\footnotetext{
* Correspondence: ZimmermannR@rki.de

${ }^{1}$ Department for Infectious Disease Epidemiology, Division for HIV/AIDS, STI

and Blood-borne Infections, Robert Koch Institute, Berlin, Germany

Full list of author information is available at the end of the article
} 
(Continued from previous page)

Results: Overall, 2,077 PWID were recruited. The range of age medians was $29-41$ years, $18.5-35.3 \%$ of participants were female, and 9.2-30.6\% were foreign born. Median time span since first injection were 10-18 years. Injecting during the last 30 days was reported by $76.0-88.4 \%$ of participants. Sharing needle/ syringes (last 30 days) ranged between 4.7 and $22.3 \%$, while sharing unsterile paraphernalia (spoon, filter, water, last 30 days) was reported by 33.0-43.8 \%. A majority of participants (72.8-85.8 \%) reported incarceration at least once, and 17.8-39.8\% had injected while incarcerated. Between 30.8 and $66.2 \%$ were currently in opioid substitution therapy. Unweighted HIV seroprevalence ranged from 0-9.1\%, HCV from 42.3-75.0 \%, and HCV-RNA from 23.1-54.0\%. The implementation of RDS as a recruiting method in cooperation with low-threshold drop in facilities was well accepted by both staff and PWID. We reached our targeted sample size in seven of eight cities.

Conclusions: In the recruited sample of mostly current injectors with a long duration of injecting drug use, seroprevalence for HIV and HCV varied greatly between the city samples. HCV was endemic among participants in all city samples. Our results demonstrate the necessity of intensified prevention strategies for blood-borne infections among PWID in Germany.

Keywords: PWID, Sero- and behavioural survey, HIV, Hepatitis C, Respondent-driven sampling, Second generation surveillance, Injecting drug users, Germany, Europe

Abbreviations: $\mathrm{Cl}$, Confidence intervals; DRUCK-study, Drugs and chronic infectious diseases study (Studie zu "Drogen und chronischen Infektionskrankheiten"); ECDC, European centre of disease prevention and control; HCV, Hepatitis C virus; HCV RNA, Hepatitis C virus ribonucleic acid; HIV, Human immunodeficiency virus; IDU, Injecting drug users; NSP, Needle and syringe exchange programme; n/s, Needles and syringes; OST, Opioid substitution treatment; PWID, People who inject drugs; RKI, Robert Koch-Institute; UNODC, United Nations Office on Drugs and Crime; RDS, Respondent-driven sampling; VCT, Voluntary testing and counselling

\section{Background}

According to estimations 15 million people were living with the hepatitis $\mathrm{C}$ virus (HCV) in the WHO European Region in 2013 [1], and 2.2 million with the human immunodeficiency virus (HIV) [2]. In most European countries people who inject drugs (PWID) are a key transmission group for blood-borne infections, including HCV and HIV [3, 4]. Studies identified several risk factors to be associated with HCV [5-11] and HIV [12, 13] infections among PWID including years of injecting, sharing of needles, syringes and other equipment, imprisonment and unprotected sex.

HIV and HCV testing are common interventions for HIV and HCV surveillance and control. They increase knowledge of HIV and HCV status, and ought to be entry points to HIV- and HCV-related treatment and care. It has been shown that opioid substitution therapy (OST) reduces injecting drug use by lowering the frequency of injecting and related unsafe practices, thereby effectively decreasing the transmission of HIV [14-16] and in combination with needle and syringes programmes (NSP) also of HCV [17]. It furthermore facilitates regular medical care and adherence to HIV and HCV treatment [18-20].

Knowledge about HIV and HCV prevalence and related behaviour amongst PWID in Germany is currently based on outdated regional studies of convenience samples. Studies providing a clear and up-to-date picture of the epidemiology of HCV and HIV amongst PWID in Germany do not exist and ongoing monitoring of infections or risk behaviours among PWID is not established. Nevertheless, regional surveys from the last decades in Germany have indicated that $\mathrm{HCV}$ is hyperendemic in PWID [21-24]. While the prevalence of HCV infection in the most recent population-based survey in the adult population was $0.3 \%$, local surveys among PWID have found prevalence ranging from 50-80\% [22-25]. High rates of infection in the PWID population were also reported from other European countries with anti-HCV prevalence ranging from 13.8 to over $90 \%$ [26]. National estimates in Germany show that PWID are also at-risk of HIV transmission. Nearly $10 \%$ of all estimated HIV infections were attributed to injecting drug use as of end of 2014 [27]. According to Backmund, in 2007 HIV prevalence among PWID in Germany must have been between 4.3 and $6.5 \%$ [28] and thus, significantly higher than in the general population, where HIV infections are below $0.1 \%$ [29]. Although there are variations across Western European countries, prevalence above $5 \%$ among PWID has been reported in France, Spain, Ireland, Greece, Portugal, and Sweden in recent years [26]. Due to preventive efforts the number of newly 
diagnosed HIV infections among PWID in Germany has been declining since a peak in the late 1980ies. In 2014, an estimated $7.5 \%$ of the 3,200 new HIV cases (240) were caused by transmission among PWID, including a sizeable proportion of approximately 25-30\% of these infections being diagnosed in Germany, but being originally acquired in Eastern or Central Europe [27]. Chronic co-infection with HCV and HIV is also common among PWID in some European countries, with a high prevalence of co-infection ranging between 15 and $70 \%$ reported by Estonia, France, Latvia, Italy, Netherlands, Poland, Portugal and Spain [30].

To tackle the risk of blood-borne and sexually transmitted infections among PWID it is essential to combine behavioural, socio-demographic and serological data to inform the planning and implementation of effective prevention and intervention strategies [31]. By identifying knowledge gaps regarding the transmission and prevention of infections, and by revealing risky and preventive practices, factors that drive transmission among PWID can be identified and addressed. Based on such information, specific recommendations for reducing risk behaviours, scaling up prevention, treatment and care can be formulated. To obtain information on the prevalence of blood-borne infections and related behaviours for PWID in Germany, we conducted a sero-behavioural study using respondent driven sampling (RDS) in eight large cities across the country in cooperation with lowthreshold drug services.

\section{Sampling hard-to-reach populations}

Standard probability methods are generally difficult to apply in hard-to-reach populations, where a sampling frame for the targeted population is not available. RDS was introduced by Heckathorn in 1997 as a modified snowball method to recruit hard-to-reach populations [32]. Globally, more than 460 studies from 69 countries applying RDS have been published, and several studies have used RDS to recruit PWID in recent years [33]. Due to their strong social networks and because PWID often buy from and inject drugs with other PWID, RDS worked well as a recruitment method in the majority of studies [34, 35]. RDS works effectively as a sampling method, when four requirements are met [32]: first, participants need to know one another through the network of the group under study. Second, the network needs to be dense enough to attain a sample with sufficient sociometric depth in order to reach equilibrium. The statistical rationale of RDS depends on the stabilization of the sample composition after a sufficient number of recruitment waves - the point at which the characteristic proportions remain stable, even if the recruitment continues is known, as the equilibrium [32]. The number of waves required to reach equilibrium is again linked to the third requirement: random recruitment must set in at some point to avoid that sampling is limited to a specific sub-group and only reflecting the characteristics of the seed with which the chain began. The tendency to recruit persons who are similar and thereby causing bias in the samples is termed homophily. Fourth, an enabling system to motivate participants to recruit other participants must be in place [36].

\section{Objectives}

In this paper we present descriptive results of the first sero-behavioural study of PWID using RDS performed in Germany. The objectives are to describe basic characteristics of participants in the respective study cities focusing on i) socio-demographic factors, ii) seroprevalence of HIV and $\mathrm{HCV}$, including co-infections, iii) use of health services, and iv) injecting and sexual risk behaviours. Furthermore, we assess whether RDS was effective for sampling PWID in the study cities.

\section{Methods}

Detailed information about methodological issues has been described earlier [37].

\section{Overview}

From 2011 to 2014, we recruited PWID using RDS across eight cities in Germany targeting a sample of 200-400 PWID in each city. All cities have a relatively large PWID community and were selected for their geographic and demographic diversity as well as the availability of low-threshold drop-in facility services. Four of the cities - Berlin, Cologne, Munich and Hamburg - have more than one million inhabitants; the four others - Essen, Leipzig, Frankfurt on the Main (Frankfurt) and Hanover- between 500,000 and 700,000.

\section{Study population}

Eligibility for participation was defined as i) aged 16 or older, ii) self-reported injecting drug use within the past 12 months in the respective city, iii) willingness to take part in an questionnaire assisted-interview and to provide a capillary blood specimen for serological and molecular testing iv) willingness to give informed consent, and v) not having participated in the study previously.

\section{Sampling method}

Sampling started with a small number of initial recruits ('seeds') in each city, selected by local partners of low threshold drug services to represent a range of characteristics (gender, country of birth, residential area and preferred low-threshold drug service, self-reported HIV serostatus, mainly preferred substance, former experience of sex work and imprisonment). All seeds were selected based on an anonymous list of PWID and their 
characteristics provided by the local partners. The recruitment expanded through so called 'recruitment waves' of peers; after the seeds recruited the first recruitment wave of participants the first recruitment wave continued to recruit the second recruitment wave of participants and so on until the targeted sample size was reached.

\section{Recruitment process}

In each city we established between one and four RDS study sites in local low-thresholds drop-in facilities, where participants enrolled in the survey and redeemed their coupons. The recruitment coupons were valid for two weeks. Each individual received 10 EUR for participating in the study, and was paid an additional 5 EUR for each eligible drug user they recruited. To ensure anonymity and to track the recruitment process we assigned a unique numeric identifier to each participant. If a seed turned out not to be productive additional seeds were selected if needed to keep the recruitment process ongoing. Recruitment and data collection was conducted by staff of low-threshold drug services who are trained to work with PWID. This recruitment process continued until the end of the scheduled recruitment period which was reached after 7 to 9 weeks.

\section{Demographic, behavioural and serological data and network information}

Staff of the Robert Koch Institute (RKI) conducted a two-day pre-survey training on study design, RDS methodology, standardised interviews, blood sample collection procedures and logistics for the staff of lowthreshold drug services in the respective study cities. Eligible PWID had to undergo a questionnaire-assisted interview in German or Russian, wherever Russianspeaking staff was available. We asked questions regarding respondent's demographic characteristics, their knowledge, attitudes, behaviour and practices as well as their network. Minor modifications were made in the questionnaire throughout the four years while conducting the survey. Therefore, some variables are not available for all cities. The network size was determined by asking respondents how many PWID (fulfilling the inclusion criteria for the study) they know by name who would also know the respondent by name. We also asked how many of these persons they believed they could recruit for the study. The questionnaire was based on a model questionnaire developed by the European Monitoring Centre for Drugs and Drug Addiction (EMCDDA), and additional indicators proposed by the European Centre of Disease Control (ECDC) and the Global AIDS response progress reporting (GARPR) [38-40]. Dried blood spots (DBS) on filter cards (Whatman \#903) were obtained from participants' capillary blood.. During the pilot phase of the study (cities of Essen and Berlin), DBS testing was validated in the Institute of Virology, National Reference Centre (NRZ) for Hepatitis C, at the University of Duisburg-Essen, which subsequently also performed the regular analyses on serological and molecular markers of HIV and HCV. The Division for HIV and other Retroviruses and the Division for Viral Gastroenteritis and Hepatitis Pathogens and Enteroviruses in the Department for Infectious Diseases at the RKI were in charge of the laboratory testing for the remaining six cities. The study flow and laboratory procedures including possible shortcomings arising from DBS testing are described in detail elsewhere [37, 41]. Prevalence of infection was determined by detection of anti HIV or anti HCV antibodies and detection of molecular markers for HIV and $\mathrm{HCV}$ by nucleic acid amplification tests. Pre- and post-test counselling were offered to participants according to international and national recommendations [42].

\section{Measures to assess the effectiveness of RDS}

For evaluation of the sampling method we applied criteria following the guidelines for "Strengthening the Reporting of Observational Studies in Epidemiology for RDS Studies" (STROBE-RDS), a checklist of essential items to present in RDS publications [33]. We provide information about the relationship of respondents with their recruiters and calculated the equilibrium and the number of recruitment waves for five key variables: I. participants' mean age; II. proportion of male participants; III. proportion of PWID born in Germany; IV. HCV prevalence; and V. HIV prevalence. Furthermore, we describe the level of homophily among the study population. Homophily $(\mathrm{Hx})$ was analysed for the following three outcomes: age, gender and HIV serology. As recommended a graphical representation of the entire recruitment network for all study cities is included. Finally, we assess whether the incentives could motivate PWID to participate in the study. Detailed material of this evaluation is attached in the Additional file.

\section{Statistical analysis}

For data entry we used EpiData 3.0. We applied descriptive statistics by using Stata version 14.0. The crude sample proportions are presented for all cities in Tables 1, 2 and 3. The results are shown as range of proportions (min. and max. values (\%)) for the respective study cities. Based on the reported network size of each participant, we used the respondent driven sampling analysis tool RDSAT version 7.1 (http://www.respondentdrivensampling.org) to define population proportions and variance estimates of each dataset [43]. We included seeds in the analysis. The number of resamplings to determine bootstrap $95 \%$ confidence 
Table 1 Socio-demographic variables, 2011-14

\begin{tabular}{|c|c|c|c|c|c|c|c|c|c|c|c|c|c|c|c|c|c|c|}
\hline & \multirow{2}{*}{\multicolumn{2}{|c|}{$\begin{array}{l}\text { Berlin } \\
n=337\end{array}$}} & \multirow{2}{*}{\multicolumn{2}{|c|}{$\frac{\text { Essen }}{n=197}$}} & \multirow{2}{*}{\multicolumn{2}{|c|}{$\frac{\text { Leipzig }}{n=130}$}} & \multirow{2}{*}{\multicolumn{2}{|c|}{$\begin{array}{l}\text { Frankfurt } \\
n=285\end{array}$}} & \multirow{2}{*}{\multicolumn{2}{|c|}{$\frac{\text { Cologne }}{n=322}$}} & \multirow{2}{*}{\multicolumn{2}{|c|}{$\frac{\text { Hanover }}{n=252}$}} & \multirow{2}{*}{\multicolumn{2}{|c|}{$\begin{array}{l}\text { Munich } \\
n=235\end{array}$}} & \multirow{2}{*}{\multicolumn{2}{|c|}{$\frac{\text { Hamburg }}{n=319}$}} & \multirow{3}{*}{$\begin{array}{l}\text { range } \\
\text { (min-max) } \\
\%\end{array}$} \\
\hline & & & & & & & & & & & & & & & & & & \\
\hline & & $n$ & $\%$ & $n$ & $\%$ & $\mathrm{n}$ & $\%$ & $n$ & $\%$ & $n$ & $\%$ & $n$ & $\%$ & $n$ & $\%$ & $n$ & $\%$ & \\
\hline \multirow[t]{2}{*}{ Age } & $\begin{array}{l}\text { Mean } \pm S \mathrm{~S} \\
\text { median; range }\end{array}$ & \multicolumn{2}{|c|}{$\begin{array}{l}35.6 \pm 8.8 \\
35.0 ; 18-60\end{array}$} & \multicolumn{2}{|c|}{$\begin{array}{l}37.9 \pm 7.9 \\
38.0 ; 19-55\end{array}$} & \multicolumn{2}{|c|}{$\begin{array}{l}29.4 \pm 7.0 \\
29.0 ; 18-55\end{array}$} & \multicolumn{2}{|c|}{$\begin{array}{l}39.6 \pm 8.7 \\
39.0 ; 20-64\end{array}$} & \multicolumn{2}{|c|}{$\begin{array}{l}39.9 \pm 8.4 \\
41.0 ; 18-62\end{array}$} & \multicolumn{2}{|c|}{$\begin{array}{l}39.0 \pm 8.7 \\
39.0 ; 19-64\end{array}$} & \multicolumn{2}{|c|}{$\begin{array}{l}38.3 \pm 8.5 \\
39.0 ; 19-63\end{array}$} & \multicolumn{2}{|c|}{$\begin{array}{l}39.8 \pm 8.9 \\
40.0 ; 17-65\end{array}$} & $29-41$ \\
\hline & $<25$ years & 30 & 9.0 & 9 & 4.6 & 35 & 26.9 & 6 & 2.1 & 11 & 3.4 & 15 & 6.0 & 16 & 6.8 & 13 & 4.1 & $2.1-26.9$ \\
\hline Gender & Female & 62 & 18.5 & 39 & 19.8 & 29 & 22.3 & 73 & 25.8 & 73 & 22.7 & 50 & 19.8 & 83 & 35.3 & 71 & 22.3 & $18.5-35.3$ \\
\hline \multirow[t]{2}{*}{ Country of birth } & Foreign-born & 103 & 30.6 & 38 & 19.3 & 12 & 9.2 & 59 & 20.7 & 67 & 20.8 & 57 & 22.6 & 39 & 16.6 & 84 & 26.3 & $9.2-30.6$ \\
\hline & $\begin{array}{l}\text { Eastern Europe } \\
\text { and Former } \\
\text { Soviet Union }\end{array}$ & 83 & 24.7 & 20 & 10.2 & 8 & 6.3 & 34 & 11.9 & 22 & 6.8 & 40 & 15.9 & 23 & 9.8 & 62 & 19.5 & $6.3-24.7$ \\
\hline \multirow[t]{4}{*}{ Educational level } & $\begin{array}{l}\text { No school } \\
\text { certificate }\end{array}$ & 52 & 15.4 & 38 & 19.4 & 17 & 13.2 & 24 & 8.5 & 67 & 20.8 & 34 & 13.5 & 20 & 8.5 & 50 & 15.8 & $8.5-20.8$ \\
\hline & $\begin{array}{l}\text { Completed lower } \\
\text { secondary } \\
\text { - 9th grade }\end{array}$ & 143 & 42.4 & 109 & 55.6 & 62 & 48.1 & 147 & 52.1 & 130 & 40.4 & 119 & 47.2 & 137 & 58.3 & 135 & 42.6 & $40.4-58.3$ \\
\hline & $\begin{array}{l}\text { Completed } \\
\text { 10th grade }\end{array}$ & 121 & 35.9 & 38 & 19.4 & 45 & 34.9 & 78 & 27.7 & 74 & 23.0 & 78 & 31.0 & 52 & 22.1 & 95 & 30.0 & $19.4-35.9$ \\
\hline & $\begin{array}{l}\text { High school } \\
\text { graduate }\end{array}$ & 21 & 6.2 & 11 & 5.6 & 5 & 3.9 & 33 & 11.7 & 51 & 15.8 & 21 & 8.3 & 26 & 11.1 & 37 & 11.7 & $3.9-15.8$ \\
\hline \multirow[t]{2}{*}{$\begin{array}{l}\text { Main source of } \\
\text { income in the } \\
\text { past } 12 \text { months }\end{array}$} & $\begin{array}{l}\text { Regular job/ } \\
\text { Unemployment } \\
\text { benefit }\end{array}$ & 56 & 16.8 & 29 & 14.7 & 25 & 19.4 & 67 & 23.8 & 59 & 18.3 & 61 & 24.2 & 67 & 28.6 & 84 & 26.8 & $14.7-28.6$ \\
\hline & $\begin{array}{l}\text { Social benefits/ } \\
\text { pension }\end{array}$ & 289 & 86.5 & 176 & 89.3 & 111 & 86.1 & 231 & 81.9 & 291 & 90.4 & 217 & 86.1 & 192 & 82.1 & 229 & 72.9 & 72.9-90.4 \\
\hline \multirow[t]{2}{*}{ Homelessness } & $\begin{array}{l}\text { In the last } \\
12 \text { months }^{c}\end{array}$ & 29 & 8.6 & 28 & 14.2 & 28 & 21.5 & 79 & 28.7 & 48 & 15.3 & 17 & 6.8 & 27 & 11.5 & 55 & 17.3 & $6.8-28.7$ \\
\hline & Ever & 216 & 64.5 & 128 & 65.0 & 100 & 76.9 & 210 & 73.9 & 218 & 68.1 & 133 & 52.8 & 139 & 59.2 & 225 & 70.8 & $52.8-76.9$ \\
\hline
\end{tabular}

${ }^{a}$ Footnote (Table 1): Because not all participants replied to every variable, some variables include missing values. This means that the city-specific denominator for some variables might be lower than the $\mathrm{n}$ displayed at the top of the table

${ }^{{ }}$Eastern Europe and Former Soviet Union: Includes PWID reporting being born in the following 24 countries: Azerbaijan, Bosnia \& Herzegovina, Bulgaria, Croatia, Czech Republic, Estonia, Georgia, Hungary, Kazakhstan, Kosovo, Kyrgyzstan, Latvia, Lithuania, Montenegro, Poland, Romania, Russian Federation, Serbia, Slovakia, Slovenia, Tajikistan, Ukraine, Uzbekistan and Yugoslavia

'Main reported form of residence, includes living on the street and in homeless shelters

intervals (CI) was set to 15,000 to improve the accuracy of the variance estimates and the network size outliers pulled in by $5 \%$. The enhanced smoothing algorithm type was employed as recommended by Johnston [44]. The RDS estimated population proportions based on the reported network are provided in the (Additional file 1: Table S1). We used RDSAT 7.1 to calculate homophily for all eight data sets. The homophily $(\mathrm{Hx})$ metric is between -1 und 1 . In line with Heckathorn's suggestion we defined any value of $\mathrm{Hx} \geq 0.3$ as intermediate homophily and any value $\leq-0.3$ as strong heterophily [45]. We applied Stata 14.0 to calculate equilibrium and the number of recruitment waves. Equilibrium was attained when the sample distribution from one recruitment wave to the next fell within a discrepancy of less than $2 \%$ [46].

\section{Results}

\section{Socio-demographic characteristics of participants}

Overall, we recruited a total of 2,079 participants in the multicentre survey, of which two did not meet our eligibility criteria. Most of the interviews took around $45 \mathrm{~min}$ to $1 \mathrm{~h}$ to complete. In each city except Leipzig $(n=130)$ a sample size between 200-400 PWID was achieved (see Table 4). In all cities the proportion of female participants ranged between 18.5 and $35.3 \%$. The median age of participants varied between 35-41 years - except in Leipzig where the median age was 29 years. Accordingly, the proportion of PWID younger than 25 years was higher in Leipzig (26.9\%) compared to the remaining seven cities (2.1-9.0\%). Leipzig was also an exception with regards to country of origin of the participants. Foreign-born participants accounted for $9.2 \%$ in Leipzig and ranged between 16.6 and $30.6 \%$ in the other seven cities. The proportion of participants born in Eastern Europe and Former Soviet Union ranged between 6.3 in Leipzig and 24.7 \% in Berlin.

The majority of participants in all cities had completed lower secondary school (40.4-58.3\%) and between 8.5 and $20.8 \%$ had not completed any school. Between 72.3-90.4 \% reported currently receiving social benefits/ 
Table 2 Serological and molecular findings for HIV and HCV and use of health care services, 2011-14

\begin{tabular}{|c|c|c|c|c|c|c|c|c|c|c|c|c|c|c|c|c|c|}
\hline \multirow[b]{3}{*}{ Serological and molecular findings } & \multirow{2}{*}{\multicolumn{2}{|c|}{$\frac{\text { Berlin }}{n=337}$}} & \multirow{2}{*}{\multicolumn{2}{|c|}{$\frac{\text { Essen }}{n=197}$}} & \multirow{2}{*}{\multicolumn{2}{|c|}{$\frac{\text { Leipzig }}{n=130}$}} & \multirow{2}{*}{\multicolumn{2}{|c|}{$\frac{\text { Frankfurt }}{n=285}$}} & \multirow{2}{*}{\multicolumn{2}{|c|}{$\frac{\text { Cologne }}{n=322}$}} & \multirow{2}{*}{\multicolumn{2}{|c|}{$\frac{\text { Hanover }}{n=252}$}} & \multirow{2}{*}{\multicolumn{2}{|c|}{$\frac{\text { Munich }}{n=235}$}} & \multirow{2}{*}{\multicolumn{2}{|c|}{$\frac{\text { Hamburg }}{n=319}$}} & \multirow{3}{*}{$\begin{array}{l}\text { range } \\
\text { (min-max) } \\
\%\end{array}$} \\
\hline & & & & & & & & & & & & & & & & & \\
\hline & $n$ & $\%$ & $n$ & $\%$ & $\mathrm{n}$ & $\%$ & $n$ & $\%$ & $\mathrm{n}$ & $\%$ & $\mathrm{n}$ & $\%$ & $n$ & $\%$ & $\mathrm{n}$ & $\%$ & \\
\hline $\mathrm{HIV+}$ & 13 & 3.9 & 12 & 6.1 & 0 & 0 & 26 & 9.1 & 5 & 1.6 & 22 & 8.7 & 7 & 3.0 & 16 & 5.0 & $0.0-9.1$ \\
\hline $\begin{array}{l}\text { HCV seroprevalence; Anti-HCV+ } \\
\text { and/or HCV-RNA+ }\end{array}$ & 185 & 54.9 & 143 & 72.6 & 55 & 42.3 & 189 & 66.3 & 229 & 71.1 & 189 & 75.0 & 149 & 63.4 & 222 & 69.6 & $42.3-75.0$ \\
\hline Cleared infection; Anti HCV+, HCV RNA- & 60 & 17.8 & 54 & 27.4 & 25 & 19.2 & 46 & 16.1 & 76 & 23.6 & 53 & 21.0 & 64 & 27.2 & 79 & 24.8 & $16.1-27.2$ \\
\hline Chronic infection; Anti HCV+, HCV RNA+ & 121 & 35.9 & 86 & 43.7 & 23 & 17.7 & 138 & 48.4 & 138 & 42.9 & 131 & 52.0 & 83 & 35.3 & 137 & 43.0 & $17.7-52.0$ \\
\hline Seroconverters; Anti HCV-, HCV RNA+ & 4 & 1.2 & 3 & 1.5 & 7 & 5.4 & 5 & 1.8 & 15 & 4.7 & 5 & 2.0 & 2 & 0.9 & 6 & 1.9 & $0.9-5.4$ \\
\hline $\begin{array}{l}\text { Co-infections: Anti HIV+, Anti HCV+ } \\
\text { and/or HCV RNA+ }\end{array}$ & 12 & 92.3 & 12 & 100.0 & - & - & 21 & 80.8 & 3 & 60.0 & 19 & 86.4 & 6 & 85.7 & 11 & 68.8 & $60.0-100.0$ \\
\hline \multicolumn{18}{|l|}{ Use of health care services and testing history } \\
\hline Use of harm reduction service (last 30d) & b & - & b & - & b & - & 256 & 90.5 & 261 & 81.3 & 221 & 87.7 & 185 & 78.7 & 284 & 89.0 & 78.7-90.5 \\
\hline Currently in OST & 135 & 40.3 & 85 & 43.2 & 40 & 30.8 & 129 & 45.3 & 213 & 66.2 & 109 & 43.3 & 129 & 55.1 & 179 & 56.3 & $30.8-66.2$ \\
\hline Ever receiving OST & 244 & 72.8 & 170 & 86.3 & 71 & 54.6 & 233 & 81.8 & 279 & 86.7 & 211 & 83.7 & 208 & 88.9 & 254 & 79.6 & $54.6-88.9$ \\
\hline Ever tested for HIV & 298 & 90.6 & 184 & 94.4 & 98 & 76.6 & 277 & 97.5 & 302 & 95.0 & 233 & 94.3 & 220 & 96.1 & 301 & 95.0 & $76.6-97.5$ \\
\hline Tested for HIV (last $12 \mathrm{~m})^{c}$ & 173 & 57.1 & 125 & 68.3 & 54 & 43.9 & 171 & 66.3 & 207 & 69.7 & 137 & 60.6 & 146 & 69.9 & 197 & 68.4 & $43.9-69.9$ \\
\hline Ever tested for HCV & 287 & 89.4 & 184 & 94.9 & 85 & 70.3 & 264 & 94.6 & 290 & 93.6 & 224 & 91.8 & 215 & 96.0 & 269 & 90.0 & 70.3-96.0 \\
\hline Tested for HCV (last $12 \mathrm{~m})^{\mathrm{d}}$ & 70 & 49.0 & 39 & 59.1 & 21 & 28.8 & 44 & 54.3 & 60 & 58.8 & 30 & 42.3 & 52 & 75.4 & 47 & 46.5 & $28.8-75.4$ \\
\hline
\end{tabular}

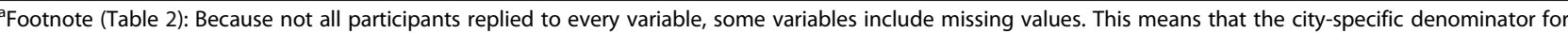
some variables might be lower than the $\mathrm{n}$ displayed at the top of the table

bdata not collected

'Excluding those with a diagnosis older than 12 months

${ }^{\mathrm{d} D e n o m i n a t o r}$ includes those never tested, those never tested positive and those who had their first HCV diagnosis in the last 12 months

pensions. Furthermore, more than half of the participants in all cities had been homeless at least once in life (52.8-76.9 \%). Between 6.8 (in Hanover) and $28.7 \%$ (in Frankfurt) of the participants reported being homeless or staying in homeless shelters as their main residence in the past 12 months (Table 1).

\section{Seroprevalence of HIV and HCV and use of health care services}

HIV prevalence amongst participants varied between $0 \%$ in Leipzig and $9.1 \%$ in Frankfurt. HCV prevalence (Anti-HCV or HCV-RNA positive or both) ranged from 42.3 in Leipzig to $75.0 \%$ in Hanover (Fig. 1), while HCV viremic infections (HCV-RNA positive) were found to range from 23.1 in Leipzig to $54.0 \%$ in Hanover. $\mathrm{HCV}$ RNA in the absence of anti-HCV antibodies was detected in $0.9 \%$ of the cases in Munich and in $5.4 \%$ of the cases in Leipzig, indicating recent $\mathrm{HCV}$ infections before seroconversion. HCV co-infections amongst the HIV positive participants were detected between $60.0 \%$ of cases in Cologne and $100 \%$ in Essen.

\section{Use of health services and testing history}

Data on utilisation of low-threshold drug services (in the last 30 days) was collected in five of the eight study cities. The proportion of PWID who visited a lowthreshold drug service in the last 30 days ranged from
78.7 to $90.5 \%$. About three out of five participants in each of the eight cities (54.6-88.9 \%) reported ever receiving opioid substitution therapy (OST). Currently receiving OST varied between 30.8 in Leipzig and $66.2 \%$ in Cologne. In all cities the vast majority had been tested for HIV during their lifetime (76.6-97.5\%). Undergoing an HIV test in the last 12 month was reported by $43.9 \%$ (Leipzig) to $69.9 \%$ (Munich). The majority of the study population in each city reported ever being tested for HCV antibodies (70.3-96.0 \%), while having been tested recently (12-month prevalence) was reported between 28.8 (Leipzig) and 75.4 \% (Munich) (Table 2).

\section{Recent substance use and risk behaviours}

The median number of years since first injection was 10 years in Leipzig, 13 years in Berlin and between 16 and 18 years in the remaining cities. In seven cities, the proportion of participants who initiated injecting in the last two years ranged from 3.2 in Hanover to $7.8 \%$ in Berlin. In Leipzig one out of ten (11.1\%) had started injecting in the last two years.

Injecting drugs in the last 30 days was reported by more than three out of four participants in all eight cities (76.0-88.4\%) and daily injection in the last 30 days varied between 17.2 in Munich and $39.1 \%$ in Berlin. In the last 30 days Heroin was the most frequently used substance (all routes of administration) in five cities 
Table 3 Substance use, sharing behaviours, sexual risks and incarceration experience, 2011-14

\begin{tabular}{|c|c|c|c|c|c|c|c|c|c|c|c|c|c|c|c|c|c|}
\hline & \multicolumn{2}{|c|}{$\begin{array}{l}\text { Berlin } \\
n=337\end{array}$} & \multicolumn{2}{|c|}{$\begin{array}{l}\text { Essen } \\
n=197\end{array}$} & \multicolumn{2}{|c|}{$\begin{array}{l}\text { Leipzig } \\
n=130\end{array}$} & \multicolumn{2}{|c|}{$\begin{array}{l}\text { Frankfurt } \\
n=285\end{array}$} & \multicolumn{2}{|c|}{$\begin{array}{l}\text { Cologne } \\
n=322\end{array}$} & \multicolumn{2}{|c|}{$\begin{array}{l}\text { Hanover } \\
n=252\end{array}$} & \multicolumn{2}{|c|}{$\begin{array}{l}\text { Munich } \\
n=235\end{array}$} & \multicolumn{2}{|c|}{$\begin{array}{l}\text { Hamburg } \\
n=319\end{array}$} & \multirow{2}{*}{$\frac{\text { range (min-max) }}{\%}$} \\
\hline & $\mathrm{n}$ & $\%$ & n & $\%$ & $\bar{n}$ & $\%$ & $\bar{n}$ & $\%$ & $\bar{n}$ & $\%$ & $\bar{n}$ & $\%$ & $\bar{n}$ & $\%$ & $\mathrm{n}$ & $\%$ & \\
\hline $\begin{array}{l}\text { Years of injecting } \\
\text { (mean } \pm \mathrm{SD} ; \\
\text { median; range) }\end{array}$ & \multicolumn{2}{|c|}{$\begin{array}{l}13.4 \pm 8.8 \\
13.0 ; 0-43\end{array}$} & \multicolumn{2}{|c|}{$\begin{array}{l}16.9 \pm 9.0 \\
17.5 ; 0-40\end{array}$} & \multicolumn{2}{|c|}{$\begin{array}{l}10.0 \pm 6.1 \\
10.0 ; 0-30\end{array}$} & \multicolumn{2}{|c|}{$\begin{array}{l}17.4 \pm 10.0 \\
16.0 ; 0-44\end{array}$} & \multicolumn{2}{|c|}{$\begin{array}{l}17.9 \pm 9.0 \\
18.0 ; 0-42\end{array}$} & \multicolumn{2}{|c|}{$\begin{array}{l}17.6 \pm 9.4 \\
18.0 ; 0-43\end{array}$} & \multicolumn{2}{|c|}{$\begin{array}{l}17.4 \pm 9.1 \\
17.5 ; 0-45\end{array}$} & \multicolumn{2}{|c|}{$\begin{array}{l}18.0 \pm 9.4 \\
18.0 ; 0-43\end{array}$} & $10.0-18.0$ \\
\hline Injecting $<2$ years & 26 & 7.8 & 10 & 5.1 & 14 & 11.1 & 14 & 4.9 & 13 & 4.0 & 8 & 3.2 & 12 & 5.2 & 19 & 6.0 & $3.2-11.1$ \\
\hline Injected drugs (last 30d) & 279 & 82.8 & 170 & 86.3 & 99 & 76.2 & 238 & 83.5 & 263 & 81.7 & 202 & 80.2 & 187 & 79.6 & 282 & 88.4 & $76.2-88.4$ \\
\hline Injected daily (last 30d) & 108 & 39.1 & 57 & 33.7 & 29 & 30.2 & 72 & 31.2 & 84 & 32.3 & 65 & 32.2 & 32 & 17.2 & 69 & 24.7 & $17.2-39.1$ \\
\hline Heroin consumed (last 30d) & 280 & 83.1 & 154 & 78.2 & 89 & 68.5 & 224 & 78.6 & 275 & 85.4 & 189 & 75.0 & 133 & 56.8 & 201 & 63.2 & $56.6-85.4$ \\
\hline Cocaine consumed (last 30d) & 125 & 37.1 & 120 & 60.9 & 23 & 17.7 & 125 & 44.0 & 150 & 46.7 & 166 & 65.9 & 49 & 20.9 & 255 & 79.9 & $17.7-79.9$ \\
\hline Crack consumed (last 30d) & 8 & 2.4 & 6 & 3.1 & 1 & 0.8 & 204 & 71.6 & 6 & 1.9 & 147 & 58.6 & 1 & 0.4 & 146 & 45.9 & $0.4-71.6$ \\
\hline Methamphetamine (last 30d) & 9 & 2.7 & 0 & 0.0 & 87 & 67.4 & 4 & 1.4 & 3 & 0.9 & 0 & 0.0 & 15 & 6.4 & 7 & 2.2 & $0.0-67.4$ \\
\hline \multicolumn{18}{|l|}{ Unsafe Use behaviour } \\
\hline $\begin{array}{l}\text { Shared needle/syringes } \\
\text { (last 30d) }\end{array}$ & 40 & 15.0 & 32 & 19.2 & 17 & 17.9 & 11 & 4.7 & 51 & 19.5 & 44 & 22.3 & 24 & 13.2 & 29 & 10.6 & $4.7-22.3$ \\
\hline $\begin{array}{l}\text { Shared equipment } \\
\text { (spoon, filter, } \\
\text { water) (last 30d) }\end{array}$ & 99 & 37.5 & 56 & 33.5 & 40 & 42.6 & 99 & 43.8 & 84 & 33.6 & 64 & 33.0 & 61 & 34.5 & 87 & 33.0 & $33.0-43.8$ \\
\hline \multicolumn{18}{|l|}{ Sexual risks } \\
\hline $\begin{array}{l}\text { Sexual intercourse } \\
\text { (last } 12 \mathrm{~m} \text { ) }\end{array}$ & 237 & 72.9 & 144 & 77.0 & 110 & 84.6 & 228 & 80.9 & 224 & 74.2 & 182 & 73.7 & 193 & 82.1 & 237 & 75.0 & $72.9-84.6$ \\
\hline $\begin{array}{l}\text { No condom use during } \\
\text { last sexual intercourse }\end{array}$ & 130 & 56.1 & 59 & 44.9 & 45 & 63.4 & 125 & 56.3 & 138 & 61.6 & 109 & 60.2 & 130 & 69.1 & 134 & 56.5 & $44.9-69.1$ \\
\hline Last sex partner was IDU & 134 & 57.5 & 73 & 51.4 & 70 & 68.6 & 139 & 65.6 & 120 & 56.1 & 105 & 64.4 & 127 & 69.4 & 118 & 54.1 & $51.4-69.4$ \\
\hline \multicolumn{18}{|l|}{ Incarceration } \\
\hline Ever incarcerated $^{a}$ & 257 & 76.5 & 169 & 85.8 & 108 & 83.1 & 239 & 84.2 & 262 & 81.9 & 214 & 85.6 & 171 & 72.8 & 254 & 79.6 & $72.8-85.8$ \\
\hline $\begin{array}{l}\text { Total duration } \\
\text { of incarceration } \\
\text { (yr) Mean } \pm S D ; \\
\text { median; range }\end{array}$ & \multicolumn{2}{|c|}{$\begin{array}{l}3.8 \pm 4.5 \\
2.0 ; 0-26\end{array}$} & \multicolumn{2}{|c|}{$\begin{array}{l}5.3 \pm 5.2 \\
4.0 ; 0-23\end{array}$} & \multicolumn{2}{|c|}{$\begin{array}{l}3.4 \pm 4.3 \\
2.0 ; 0-24\end{array}$} & \multicolumn{2}{|c|}{$\begin{array}{l}5.1 \pm 5.5 \\
3.0 ; 0-29\end{array}$} & \multicolumn{2}{|c|}{$\begin{array}{l}4.8 \pm 5.0 ; \\
3.0 ; 0-23\end{array}$} & \multicolumn{2}{|c|}{$\begin{array}{l}6.5 \pm 6.3 \\
5.0 ; 0-30\end{array}$} & \multicolumn{2}{|c|}{$\begin{array}{l}3.2 \pm 3.6 \\
2.0 ; 0-15\end{array}$} & \multicolumn{2}{|c|}{$\begin{array}{l}5.0 \pm 4.9 ; \\
4.0 ; 0-20\end{array}$} & $2.0-5.0$ \\
\hline Injecting in prison (ever) & 101 & 39.3 & 55 & 32.7 & 19 & 17.8 & 59 & 24.7 & 78 & 29.9 & 78 & 37.0 & 35 & 20.5 & 70 & 27.7 & $17.8-39.3$ \\
\hline $\begin{array}{l}\text { Shared needle/syringes/ } \\
\text { equipment (among those } \\
\text { injecting during their } \\
\text { last imprisonment) }\end{array}$ & 32 & 33.0 & 20 & 37.7 & 7 & 38.9 & 20 & 36.4 & 38 & 49.4 & 32 & 41.0 & 14 & 40.0 & 33 & 48.5 & $33.0-49.4$ \\
\hline $\begin{array}{l}\text { Unprofessionally } \\
\text { tattooed/pierced } \\
\text { in prison (ever) }\end{array}$ & 81 & 24.2 & 67 & 34.5 & 39 & 32.2 & 79 & 27.8 & 97 & 30.2 & 76 & 30.3 & 45 & 19.4 & 71 & 22.3 & $19.4-34.5$ \\
\hline
\end{tabular}

Including juvenile arrest/prison, pre-trial custody, prison, forensic commitment

${ }^{b}$ Footnote (for Table 3): Because not all participants replied to every variable, some variables include missing values. This means that the city-specific denominator for some variables might be lower than the $\mathrm{n}$ displayed at the top of the table

(Berlin: 83.1 \%; Essen: 78.2 \%; Cologne: 85.4 \%; Hanover: $75.0 \%$ and Munich $56.8 \%$ ); while in Leipzig methamphetamine was the most frequently reported substance $(67.4 \%)$. In the other seven cities methamphetamine was less common (0.0-6.4\%). Crack was used by a high proportion of participants in three cities (Frankfurt: 71.6 \%; Hanover: $58.6 \%$ and Hamburg: $45.9 \%$ ) while reported by much lower proportions in the remaining five cities (0.4-3.1\%). Cocaine use was lower in Berlin (37.1 \%), Leipzig (17.7 \%) and Munich (20.9 \%) compared to Frankfurt (44.0\%), Cologne (46.7 \%), Essen
(60.9 \%), Hanover (65.9 \%) and Hamburg (79.9\%). Sharing of unsterile needles and syringes $(n / s)$ in the last 30 days was reported by $10.6 \%$ in Hamburg and up to $22.3 \%$ in Hannover among participants who reported having injected during the last 30 days.; only in Frankfurt the proportion was lower (4.7\%). Recent sharing of unsterile equipment like spoons, filters or water for injection with other injectors was reported by $33.0 \%$ in Hanover and Hamburg and by up to $43.8 \%$ in Frankfurt among persons who injected during the last 30 days. 
Table 4 Details of the recruitment procedures using RDS in eight German cities, 2011-14

\begin{tabular}{|c|c|c|c|c|c|c|c|c|}
\hline & $\begin{array}{l}\text { Berlin } \\
(n=337)\end{array}$ & $\begin{array}{l}\text { Essen } \\
(n=197)\end{array}$ & $\begin{array}{l}\text { Leipzig } \\
(n=130)\end{array}$ & $\begin{array}{l}\text { Frankfurt } \\
(n=285)\end{array}$ & $\begin{array}{l}\text { Cologne } \\
(n=322)\end{array}$ & $\begin{array}{l}\text { Hanover } \\
(n=252)\end{array}$ & $\begin{array}{l}\text { Munich } \\
(n=235)\end{array}$ & $\begin{array}{l}\text { Hamburg } \\
(n=319)\end{array}$ \\
\hline Target sample size & $300-350$ & 200 & 200 & 300 & 300 & $200-250$ & 200 & 300 \\
\hline Month and year of recruitment & 05-07. 2011 & 10-12. 2011 & $10-12.2012$ & 01-03.2013 & 04-05.2013 & 07-09.2013 & $10-12.2013$ & 03-05.2014 \\
\hline Time of recruitment & 8 weeks & 8 weeks & 7 weeks & 9 weeks & 8 weeks & 8 weeks & 8 weeks & 8 weeks \\
\hline No. of study sites & 4 & 1 & 2 & 2 & 1 & 1 & 1 & 1 \\
\hline No. of seeds in total & 19 & 18 & 13 & 11 & 12 & 7 & 13 & 9 \\
\hline No. of unproductive seeds & 4 & 6 & 4 & 2 & 0 & 4 & 3 & 0 \\
\hline Max. number of recruitment waves & 13 & 10 & 8 & 20 & 13 & 14 & 14 & 20 \\
\hline Coupon received from partner & a & a & $7 \%$ & $5 \%$ & $2 \%$ & $4 \%$ & $3 \%$ & $2 \%$ \\
\hline Coupon received from acquaintance & a & a & $78 \%$ & $64 \%$ & $84 \%$ & $50 \%$ & $67 \%$ & $65 \%$ \\
\hline Coupon received from stranger & a & a & $15 \%$ & $31 \%$ & $14 \%$ & $46 \%$ & $30 \%$ & $33 \%$ \\
\hline
\end{tabular}

${ }^{a}$ data on the relationship to the recruiter was not collected in first two study cities

\section{Sexual risk behaviours}

Between 72.9 and $84.6 \%$ of participants reported engaging in sexual intercourse in the last 12 months, of which 44.9 \% in Essen and up to $69.1 \%$ in Munich reported not having used a condom at last sexual intercourse. More than half of the participants reported that their last sexual partner was also injecting drugs $(51.4 \%$ in Essen and up to $69.4 \%$ in Munich).

\section{History of incarceration}

Imprisonment (ever) was reported by the majority of participants in all cities (72.8-85.8\%) and median of total duration of incarceration ranged between 2.0 years in Leipzig, Berlin and Munich to 5.0 years in Hanover. Of those who had ever been in prison, between $17.8 \%$ in Leipzig and $39.3 \%$ in Berlin reported injecting drugs while incarcerated. Of these, between 33.0 and $49.4 \%$ had shared $\mathrm{n} / \mathrm{s}$ or other equipment when injecting during their last incarceration. Tattooing and piercing during imprisonment were reported by $19.4 \%$ of the participants in Munich and up to $34.5 \%$ of the participants in Essen.

The detailed data on substance use and risk behaviours in the last 30 days are shown in Table 3.

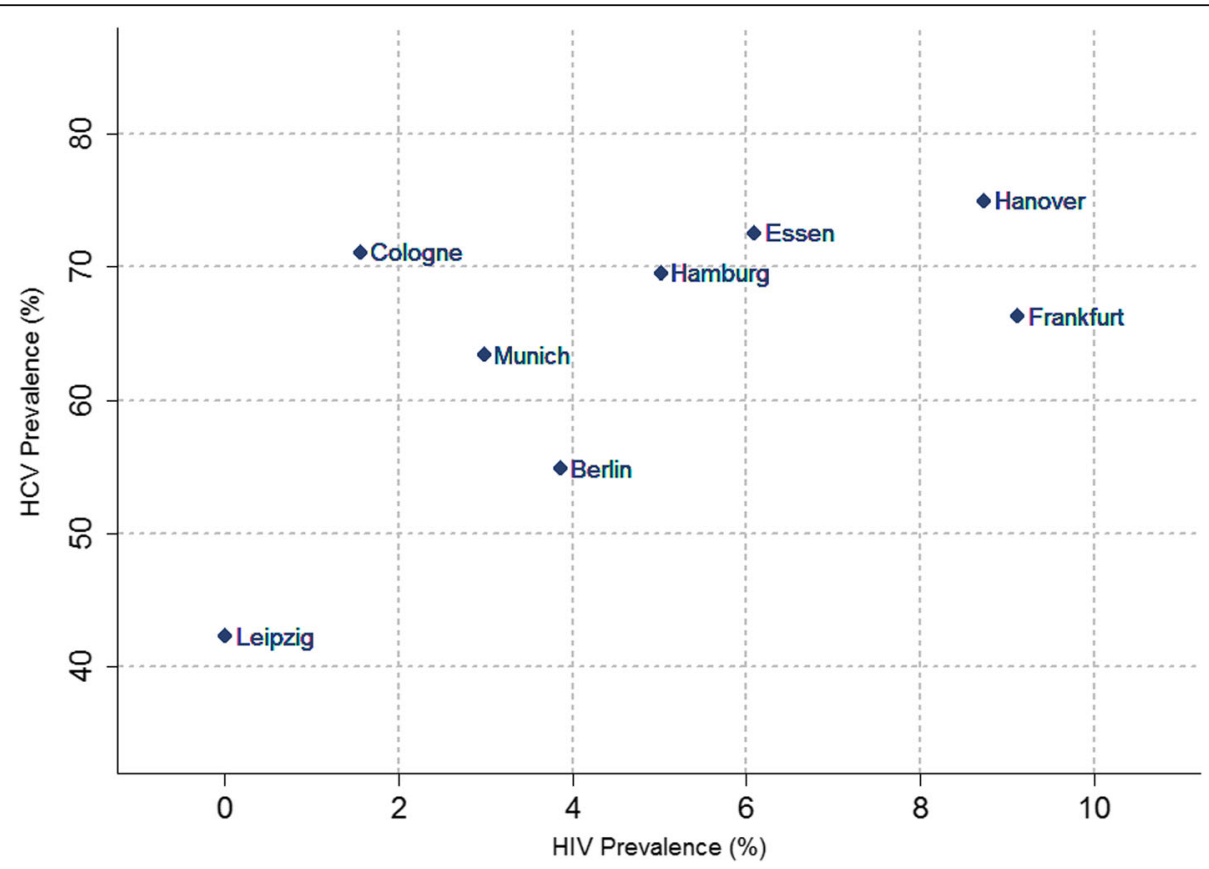

Fig. $1 \mathrm{HIV}$ and HCV seroprevalence in the eight cities (\%) 


\section{Evaluation of the sampling method: respondent driven sampling}

Between 7 and 19 seeds started the recruitment process in the respective cities. The sample of Leipzig $(n=130)$ reached a maximum of eight recruitment waves, while the samples of Frankfurt and Hamburg reached a maximum of 20 recruitment waves (Table 4). Equilibrium and homophily were assessed after the recruitment process had been completed. We reached equilibrium for four of the following five key variables: I. participants' median age; II. proportion of male participants; III. proportion of PWID born in Germany; IV. HCV prevalence; and V. HIV prevalence in all study cities except in Leipzig. Equilibrium for HIV prevalence was not attained in our sample of Frankfurt, Hanover and Cologne. The results of these analyses are presented in the (See Additional file 2: Figure S1a, Additional file 3: Figure S1b, Additional file 4: Figure S1c, Additional file 5: Figure S1d, Additional file 6: Figure S1e and Additional file 7: Figure S2). Respondents and recruiters had the following relationships: Most participants (54-86 \%) received their coupons from their partner or from an acquaintance. Between $14 \%$ of the participants in Cologne and up to $46 \%$ of the participants in Hanover received their coupons from a stranger (Table 4). The reported network size defined as "how many people who injected drugs in the last 12 months do you know (and they know you)" ranged from 0-1400 individuals. We did observe random recruitment among the participants. In Frankfurt, Cologne and Hamburg young participants ( $<25$ years) demonstrated a strong negative homophily, indicating that younger participants only recruited older participants $(\mathrm{Hx}$ $=-1$ ). Among the female participants, only women in Leipzig demonstrated a negative homophily $(\mathrm{Hx}=-0.37)$. In Cologne and Munich HIV positive participants only recruited HIV negative participants $(\mathrm{Hx}=-1)$ while HIV negative participants in Cologne demonstrated intermediate homophily recruiting mostly other HIV negative participants $(\mathrm{Hx}=0.67)$. The recruitment chains in Cologne and Hamburg show a very late recruitment of HIV positive PWID in the study sample (See Additional file 8: Figure S4e and Additional file 9: Figure S4h). In those two city samples the recruitment chains have often ended once HIV positive participants were recruited. A graphical representation of the recruitment networks (including HIV and HCV serostatus) in each study city is displayed in the (See Additional file 10: Figure S4a-b, Additional file 11: Figure S4c-d, Additional file 8: Figure S4e-f, Additional file 9: Figure S4g-h).

In all cities we observed a decreased interest in participation in the days following the monthly "social benefit"-payment. We did not experience recruitment challenges such as commercial exchange of coupons, imposters or duplicate recruits.

\section{Discussion}

This paper presents first findings of the first large bio-behavioural survey among PWID using RDS in Germany. With a study sample of 2,077 participants, the results of the study provide recent data on current $\mathrm{HCV}$ and HIV prevalence, socio-demographical factors and behaviours among PWID in Germany. Our results show that $\mathrm{HCV}$ is endemic among the study populations (42.3$75.0 \%$ ). This result is similar to estimations from available regional surveys and reported data from several European countries [47]. Viremic HCV infections among the participants were found to range between $23.1-54.0 \%$. In contrast to previous findings from sub-regional surveys in Germany [28], HIV prevalence varied widely between the city samples ranging from $0 \%$ in Leipzig to $9.1 \%$ in Frankfurt. HIV prevalence of more than $5 \%$ was found in four of the city samples. These results are higher compared to reported data on the HIV prevalence in PWID in many other Western European countries, such as the United Kingdom, Denmark, Norway, Austria, or Luxemburg, but still lower than in countries like Italy, Portugal and France [48].

HIV and HCV seroprevalences were both found to be geographically heterogeneous. While Leipzig was the city sample with the lowest prevalences, participants in Essen, Hanover and Frankfurt had high levels of HIV and HCV infections. The differences between the locations might be due to several factors. We identified three characteristics that might be associated with the different levels of HIV and HCV prevalence across the cities: First, age (closely linked with duration of injecting), second, drug use patterns in each city and third, the history of intravenous drug use and the HIV epidemic in the region. In Essen, Hanover and Frankfurt (all city samples with high levels of HIV and HCV infections) study participants were generally older and duration of injecting was longer than in Leipzig. This is consistent with the trend of aging injecting drug user-populations in Germany and Europe at large. The longer a person has injected drugs, the more likely it is that this person will have been exposed to blood-borne pathogens [5]. The sample of Cologne seems to be an exception with an unexpected low HIV seroprevalence. However, as described, in this city HIV-positive persons were recruited only in a late stage of the recruitment process shortly before the end of the study. We therefore might underestimate the true HIV prevalence in this city sample. Further research will be needed to explain this discrepancy.

The different HCV and HIV prevalence might also be associated with the varying use of cocaine, crack and methamphetamines in the cities. Cocaine was found to be most common in Hamburg, Hanover and Essen while crack was mostly used in Frankfurt, Hanover 
and Hamburg, all of which are cities with a high HIV and $\mathrm{HCV}$ prevalence. Cocaine and crack have a shorter biological half-life and need to be consumed more frequently than other substances in order to maintain their effect $[49,50]$. PWID who use cocaine or crack may consequently be more exposed to unsafe use than PWID who use substances requiring less injections. Methamphetamine was found to be most common in Leipzig. This confirms an increasing trend of methamphetamine use in border regions to Czech Republic like Saxony reported in the last years [51-54]. Methamphetamine has a longer biological half-life than heroin and may thus be less frequently injected [55]. Furthermore, the distinct demographic characteristics and consumption patterns in Leipzig might be related to the division of Germany to East and West until 1990. A drug scene in the former East probably developed only after the German re-unification in 1990. While HIV incidence among PWID in West Germany peaked in the mid-1980s, in the Eastern part of Germany the spread of HIV was delayed in time [56]. The delayed epidemic of intravenous drug use and associated blood-borne infections in East Germany are reflected in our results. According to the national HIV case-reporting system HIV is present among PWID in Leipzig with two reported cases in 2012 and three in 2015 [57]. This indicates an ongoing HIV transmission, albeit on a low level [58]. In our sample of Leipzig, we found the highest proportion of new injectors and the highest proportion of participants testing HCV RNA-positive in the stage of seroconversion, likewise indicating ongoing transmissions. This result is consistent with evidence that $\mathrm{HCV}$ incidence is rapidly increasing among new injectors $[7,59]$.

\section{Injecting and sexual risk behaviours}

Risk behaviours (30-day prevalence) like using unsterile paraphernalia (spoons, filters or water), sharing of unsterile $n / s$ and practicing unsafe sex, also with non-IDU (12month prevalence), was reported in all city samples. In the last two decades, harm reduction interventions like NSP in high income countries, including Germany have led to a remarkable decline in the re-use of unsterile $\mathrm{n} / \mathrm{s}$ and in HIV incidence among PWID [60-63]. From our findings we must conclude that either the access to clean $\mathrm{n} / \mathrm{s}$ is still insufficient and/or that there are still knowledge gaps around transmission and preventive behaviour of HIV and HCV. In other studies, sharing of other paraphernalia still persists at higher levels than sharing $\mathrm{n} / \mathrm{s}$ among PWID [64-66]. This was also reflected in our study: sharing other paraphernalia appeared much more common than sharing $\mathrm{n} / \mathrm{s}$ which was most prevalent in the sample of Frankfurt. In this particular case, the high discrepancy might be related to the high number of crack users. Crack is generally linked to a high consumption frequency, and thus with an increased use of paraphernalia.
Several studies have demonstrated that HCV is more infectious than HIV and a prolonged survival of $\mathrm{HCV}$ in syringes and non-syringe injecting paraphernalia has been shown $[67,68]$. Not surprisingly and in line with data from other Western European countries, HCV infections therefore appeared to be more prevalent within the study population than HIV [26].

High proportions of the participants reported that their last sexual intercourse was unprotected. The last sexual partner was frequently reported to be an injecting drug user as well, but it was also not uncommon that the sexual partner was a non-PWID. The reported sexual behaviours thus demonstrate the potential risk of spreading HIV through the sexual route. While other studies have demonstrated the higher risk of non-PWID to acquire HIV [69], in Germany, little is known about HIV prevalence among the non-injecting sexual partners of PWID and their potential risk of being a bridge population between PWID and the general population. Therefore further research is needed to better understand the HIV/ HCV prevention needs of sex partners of PWID who do not inject drugs themselves.

The study found high rates of incarceration (at least once in lifetime) among the study participants. Unsafe drug use and tattooing/piercing in prison were reported as common practices while in prison, thus constituting important risk factors for the transmission of HIV and HCV. Several studies have shown that not only drug use but also HIV and HCV infections among people in prison are of major concerns in Germany [70, 71]. The provision of harm reduction services in the criminal justice system seems to be insufficient, only one of 186 prisons in Germany offers NSP [72], and there are large variations regarding the availability of OST in prisons across the federal states [70, 73].

Our study shows that HCV and HIV testing rates (12-month prevalence) remained moderate to high in the study populations in comparison to other risk groups, like men who have sex with men [74]. Especially the large variation in the $\mathrm{HCV}$ testing rates across the study cities may be linked to the variation of participants who reported undergoing OST at the time of participating, but this needs further investigation.

An important limitation of our study is that it only provides a snap shot of the HIV and HCV epidemiology among PWID in Germany but it does not allow determination of cause-effect relationships. Furthermore, the selection of our study cities was based on the availability of low-threshold drug services in the cities willing and able to participate in the study. Since national representative data on PWID in Germany are not available, we cannot claim that the PWID recruited in the chosen cities are representative for all PWID in Germany. 


\section{Respondent driven sampling}

The application of RDS as a method to recruit PWID was successful. We reached the targeted sample size within the set time frames in all cities except in one, and our primary and secondary incentives seemed appropriate to motivate PWID to enroll in the study. This is in line with other studies, showing that RDS is an effective recruitment method among PWID [35, 75].

The choice of low-threshold drug services as study venues probably increased the willingness of participation. We observed long recruitment chains in seven of the eight city samples, indicating that PWID are well connected via social networks or through making use of the lowthreshold drug services. However, we cannot exclude selection bias of the city samples due to oversampling of persons as initial seeds as well as participants who showed communicative competence, well understood the study flow and the background of the study, and who were willing to recruit others for participation. Persons with a lower bonding to the drug scene or less communicative skills might be underrepresented in the samples.

Due to the extensive questionnaire, we refrained from asking the participants how many PWID rejected their coupons during the recruitment process. Reasons for rejecting and the number of PWID who refused are therefore unknown. It is possible that unknown barriers restricted participation and potentially created a bias. Yet we assume that our samples mostly attained adequate socio-metric depth, given that equilibrium was reached for four out of five key variables while reaching up to 20 waves in our samples. However, not all city samples allow robust weighting of results, as equilibrium was not reached in all and the length of the recruitment chains was too short in the city of Leipzig. In this city we recruited PWID in two low-threshold drug services with alternating study operating hours. This seems to have confused some study participants and it is possible that further potential participants were lost due to this fact. Equilibrium could be reached in the other seven samples, showing that bias introduced by the initial non-randomly selected seeds could be eliminated in these samples.

Despite the popularity and the widely applied methodology of RDS as a sampling method it is not known whether RDS can generate unbiased estimates. The assessment of RDS as a method of data analysis (RDS inference) is challenging as it often fails to produce precise results due to the unknown underlying truth [76]. Also, the key variable used to generate the RDS-generated estimates is the reported network size of the participant which may not have been consistently addressed by all interviewers or not consistently understood by all participants, leading to a large range and thereby further uncertainty about the validity of the RDS estimates. In 2012 McCreesh et al. have performed a RDS study with known characteristics in order to assess the precision and relevance of RDS inference and found that RDS failed to reduce bias when it occurred, and even tended to overestimate biased adjusted results [77]. In case biases occur in practice the method is not designed to correct for the sources of biases. RDS-generated estimates should therefore be interpreted with caution and are only shown in the Additional file 1: Table S1.

\section{Conclusions}

To best of our knowledge this study is the first biobehavioural study using RDS in Germany successfully recruiting members of the target population. This paper presents basic descriptive results for key variables in all of the eight study cities. HCV was found to be hyperendemic within the study population. HIV and HCV seroprevalence were geographically heterogeneous, although unsafe use behaviour, such as sharing $\mathrm{n} / \mathrm{s}$ and other paraphernalia, unsafe sex, and incarceration was common among all city samples.

Based on our findings, efforts to reduce sharing of non-syringe paraphernalia and to further reduce the use of unsterile $\mathrm{n} / \mathrm{s}$ are urgently needed in Germany. We furthermore recommend to scale up and increase the access to multilevel and combined HCV and HIV prevention, including antiviral treatment, OST and voluntary counselling and testing (VCT) for PWID. Our study suggests that there might be opportunities to better integrate VCT services in low-threshold drug services, as they were used by up to $90 \%$ of the participants (30-day prevalence). Based on the large regional differences observed in our study, we suggest developing context specific interventions. Harm reduction programmes should particularly consider new injectors. Internationally, there is consensus in the scientific discourse about the need to provide prevention, treatment and care interventions for all, people living in freedom as well as for prisoners [78].

Further in-depth analyses of the collected data will reveal possible associations between infections and behavioural factors and other characteristics, to derive concrete recommendations for current prevention strategies for HCV and HIV among PWID.

\section{Additional files}

Additional file 1: Sample proportion and estimated population proportion estimates for all variables. (XLS $75 \mathrm{~kb}$ )

Additional file 2: HCV prevalence. (TIF $566 \mathrm{~kb}$ )

Additional file 3: HIV prevalence in all study cities except in Leipzig. (TIF $518 \mathrm{~kb}$ )

Additional file 4: Proportion of male participants. (TIF $535 \mathrm{~kb}$ )

Additional file 5: Proportion of participants born in Germany. (TIF 628 kb) Additional file 6: Participants' median age. (TIF $494 \mathrm{~kb}$ ) 
Additional file 7: Number of recruits per recruitment wave. (TIF 695 kb)

Additional file 8: Sample of Cologne (2013); $n=322$ (12 seeds) and sample of Hanover (2013); $n=252$ (7 seeds). (TIF 537 kb)

Additional file 9: Sample of Munich (2013); $n=235$ (13 seeds) and sample of Hamburg (2014); n=319 (9 seeds). (TIF 500 kb)

Additional file 10: Sample of Berlin (2011); $n=337$ (19 seeds) and sample of Essen (2011); $n=197$ (19 seeds). (TIF $296 \mathrm{~kb}$ )

Additional file 11: Sample of Leipzig (2012); $n=130$ (13 seeds) and sample of Frankfurt (2013); n=285 (11 seeds). (TIF 377 kb)

Additional file 12: Homophily $(\mathrm{Hx})$ in eight city samples (age, gender, HIV seroprevalence). Cities: Berlin (B), Essen (E); Leipzig (L); Frankfurt (F); Cologne (C); Hanover $(\mathrm{H})$; Munich $(\mathrm{M})$; Hamburg $(\mathrm{HH})$. The homophily $\mathrm{Hx}$ shows the tendency of individuals in a group having social bonds with other individuals similar to them. $\mathrm{Hx}=0$ means that the formation of social bonds is independent of group membership. $\mathrm{Hx}=1$ mean no social bonds to outsiders exist. $\mathrm{Hx}=-1$ means all social bonds are formed with people outside the group [44]. (TIF $690 \mathrm{~kb}$ )

\section{Acknowledgements}

The authors would like to thank all study participants and all staff members of the low-threshold-drug services for the cooperation. We acknowledge Rieke Barbek, Serdar Danis, Lineke Derks, Maria Friedrich, Nicole Hecht, Sami Marzougui, Doreen Gavrielov, Eva Pedersen, Judith Stumm, Andrea Teti and Weidong Zhang for their contributions in questionnaire design, logistic assistance, data entry and validation during the study, and Matthias an der Heiden and Ramona Scheufele for giving statistical advice. During the pilot, Jessica Ackermann, Ewa Bayrambasi, Ulrike Büttner, Sylvia Dziubek, Irina Jakobsche, Britta Krellenberg, Jadwiga Piejek, Anna Metcalf, Silke Saar, and Melanie Schröter gave technical assistance in the laboratory. We are grateful for the excellent technical assistance of Nadine Kutzner, Claudia Zymelka, Ute Obst, Sabrina Neumann, Katrin Arndt, Hanno von Spreckelsen, Joana Tziolis, Estelle Kenfack Guepi and Guido Vogt. Thanks to the sequencing service of the RKI (ZBS1) for support of the study. DRUCK Study group

Vikas Bapat (Fixpunkt Step Hannover gGmbH; vikas.bapat@step-hannover.de) Johannes Bombeck (Suchthilfe direkt Essen gGmbH; bombeck@suchthilfedirekt.de); Kerstin Dettmer (Fixpunkt Berlin e.V.; K.Dettmer@fixpunkt.org); Andreas Hecht (Sozialdienst Katholischer Männer e.V.; andreas.hecht@ skm-koeln.de); Werner Heinz (Jugendberatung und Jugendhilfe e.V.; werner.heinz@jj-ev.de); Christiane Kerres (Step -Paritätische Gesellschaft für Sozialtherapie und Pädagogik mbH; christiane.kerres@step-hannover.de); Jürgen Klee (Aids-Hilfe Frankfurt e.V.; Juergen.Klee@frankfurt.aidshilfe.de); Astrid Leicht (Fixpunkt Berlin e.V.; A.Leicht@fixpunkt.org); Sylke Lein (Stadt Leipzig, Gesundheitsamt - Suchtbeauftragte; sylke.lein@leipzig.de); Bärbel Marrziniak (Suchthilfe direkt Essen gGmbH; marrziniak@suchthilfe-direkt.de); Olaf Ostermann (Condrobs e.V.; olaf.ostermann@condrobs.de); Prof. Dr. Norbert Scherbaum (Klinik für abhängiges Verhalten und Suchtmedizin, LVR-Klinikum Essen, Kliniken/Institut der Universität Duisburg-Essen; norbert.scherbaum@uni-due.de); Dirk Schäffer (Deutsche Aids-Hilfe e.V.; dirk.schaeffer@dah.aidshilfe.de); Ina Stein (Stadt Leipzig, Gesundheitsamt; ina.stein@leipzig.de); Lutz Wiederanders (Stadt Leipzig, Amt für Jugend, Familie und Bildung - Straßensozialarbeit; lutz.wiederanders@leipzig.de).

\section{Funding}

This study was funded by the Robert Koch Institute (pilot) and the German Federal Ministry of Health. The German Federal Ministry of Health was neither involved in the study design, in the collection, analysis and interpretation of the data, nor in the writing of the publication.

\section{Availability of data and materials}

All data generated or analysed during this study are included in this published article (Tables 1, 2, 3, 4 and Fig. 1) and in supplementary information files (Additional file 1: Table S1, Additional file 2: Figure S1a, Additional file 3: Figure S1b, Additional file 4: Figure S1C, Additional file 5: Figure S1d, Additional file 6: Figure S1e, Additional file 7: Figure S2, Additional file 12: Figure S3 and Additional file 10: Figure S4a-b, Additional file 11: Figure S4c-d, Additional file 8: Figure S4e-f, Additional file 9: Figure S4g-h).

\section{Authors' contributions}

BW drafted the manuscript and performed the RDS sample analysis. RZ and UM designed the study and were supported by CSH, D. Schaeffer (Deutsche Aids-Hilfe e.V.), A. Leicht (Fixpunkt e.V), K. Dettmer (Fixpunkt e.V.) and OH. BW and SN were scientific coordinators of the study. RSR validated laboratory procedures for DBS testing and analysed the samples during the pilot phase of the study in 2011. CK, CTB and NB validated and performed laboratory testing since 2012. WC supported the analysis of the laboratory testing data. The manuscript was critically revised by SN, MG, CSH, WC, RSR, CTB, BAR, CK, $\mathrm{NB}, \mathrm{VB}, \mathrm{OH}, \mathrm{UM}, \mathrm{RZ}$. All authors participated in the critical discussion of the results, and contributed to and have approved the final manuscript. The DRUCK-Study group approved the final manuscript as well.

\section{Competing interests}

R.S. Ross in the past received honoraria from Abbott Diagnostics and Siemens Healthcare Diagnostics for delivering talks and conducting analytical evaluations of diagnostic kits. All other authors declare that they do not have any competing interests.

\section{Consent for publication}

\section{Not applicable.}

\section{Ethical approval and consent to participate}

Ethical approval was received from the ethics committee at Charité University Medicine, Berlin, Germany, in May 2011 (Number EA4/036/11) and in November 2012 (amendment; Number EA4/036/11).

The Federal Commissioner for Data Protection and Freedom of Information approved the study protocol on 29/11/2012 (III-401/008\#0035).

All participants signed an informed consent form to allow their anonymous data to be used for publication.

\section{Author details}

${ }^{1}$ Department for Infectious Disease Epidemiology, Division for HIV/AIDS, STI and Blood-borne Infections, Robert Koch Institute, Berlin, Germany. ${ }^{2}$ Charité University Medicine, Berlin, Germany. ${ }^{3}$ Institute of Virology, National Reference Centre for Hepatitis C, University Hospital Essen, University of Duisburg-Essen, Essen, Germany. ${ }^{4}$ Department of Infectious Diseases, Division for Viral Gastroenteritis and Hepatitis Pathogens and Enteroviruses, Robert Koch Institute, Berlin, Germany. ${ }^{5}$ Department of Infectious Diseases, Division for HIV and other Retroviruses, Robert Koch Institute, Berlin, Germany.

Received: 27 February 2016 Accepted: 18 August 2016 Published online: 05 September 2016

\section{References}

1. Hope VD, Eramova I, Capurro D, Donoghoe MC. Prevalence and estimation of hepatitis $B$ and $C$ infections in the WHO European region: a review of data focusing on the countries outside the European union and the European free trade association. Epidemiol Infect. 2014;142(2):270-86.

2. Joint United Nations Programme on HIV/AIDS (UNAIDS). UNAIDS Report on the Global AIDS Epidemic 2013. Geneva: Joint United Nations Programme on HIV/AIDS (UNAIDS); 2013.

3. Wiessing L, Guarita B, Giraudon I, Brummer-Korvenkontio H, Salminen M, Cowan S. European monitoring of notifications of hepatitis $C$ virus infection in the general population and among injecting drug users (IDUs)-the need to improve quality and comparability. Euro Surveill. 2008;13(21). Available online: http://www.eurosurveillance.org/ViewArticle.aspx?Articleld=18884.

4. Wiessing L, Likatavicius G, Hedrich D, Guarita B, van de Laar MJ, Vicente J. Trends in HIV and hepatitis $C$ virus infections among injecting drug users in Europe, 2005 to 2010. Euro Surveill. 2011;16(48):9-13.

5. Hope VD, Hickman M, Ngui SL, Jones S, Telfer M, Bizzarri M, Ncube F, Parry $J V$. Measuring the incidence, prevalence and genetic relatedness of hepatitis $C$ infections among a community recruited sample of injecting drug users, using dried blood spots. J Viral Hepat. 2011;18(4):262-70.

6. Yen Y-F, Yen M-Y, Su L-W, Li L-H, Chuang P, Jiang X-R, Deng C-Y. Prevalences and associated risk factors of HCV/HIV co-infection and HCV mono-infection among injecting drug users in a methadone maintenance treatment program in Taipei, Taiwan. BMC Public Health. 2012;12(1):1066.

7. Maher $L$, Jalaludin B, Chant KG, Jayasuriya R, Sladden T, Kaldor JM, Sargent $\mathrm{PL}$. Incidence and risk factors for hepatitis $\mathrm{C}$ seroconversion in injecting drug users in Australia. Addiction. 2006;101(10):1499-508. 
8. Cullen KJ, Hope VD, Croxford S, Shute J, Ncube F, Parry JV. Factors associated with recently acquired hepatitis $C$ virus infection in people who inject drugs in England, Wales and Northern Ireland: new findings from an unlinked anonymous monitoring survey. Epidemiol Infect. 2015;143(7):1398407. doi:10.1017/S0950268814002040.

9. De P, Roy E, Boivin JF, Cox J, Morissette C. Risk of hepatitis C virus transmission through drug preparation equipment: a systematic and methodological review. J Viral Hepat. 2008;15(4):279-92.

10. Pouget ER, Hagan H, Des Jarlais DC. Meta-analysis of hepatitis C seroconversion in relation to shared syringes and drug preparation equipment. Addiction. 2012;107(6):1057-65.

11. Hagan H, Pouget ER, Des Jarlais DC. A systematic review and meta-analysis of interventions to prevent hepatitis $C$ virus infection in people who inject drugs. J Infect Dis. 2011;204(1):74-83.

12. Des Jarlais DC. Variability in the incidence of human immunodeficiency virus, hepatitis B virus, and hepatitis $C$ virus infection among young injecting drug users in New York City. Am J Epidemiol. 2003;157(5):467-71.

13. Des Jarlais D, Semaan S. HIV and other sexually transmitted infections in injection drug users and crack cocaine smokers, Sexually transmitted diseases. 4th ed. New York: McGraw-Hill; 2008. p. 237-55.

14. Gowing L, Farrell MF, Bornemann R, Sullivan LE, Ali R. Oral substitution treatment of injecting opioid users for prevention of HIV infection. Cochrane Database Syst Rev. 2011:8:CD004145.

15. Sorensen JL, Copeland AL. Drug abuse treatment as an HIV prevention strategy: a review. Drug Alcohol Depend. 2000;59(1):17-31.

16. Tilson H, Aramrattana A, Bozzette S, Celentano D, Falco M, Hammett T, Kozlov A, Lai S, Mahal A, Schottenfeld R. Preventing HIV infection among injecting drug users in high-risk countries: an assessment of the evidence. Washington, DC: Institute of Medicine; 2007

17. Turner KM, Hutchinson S, Vickerman P, Hope V, Craine N, Palmateer N, May M, Taylor A, De Angelis D, Cameron S. The impact of needle and syringe provision and opiate substitution therapy on the incidence of hepatitis $C$ virus in injecting drug users: pooling of UK evidence. Addiction. 2011; 106(11):1978-88.

18. Malta M, Strathdee SA, Magnanini MM, Bastos Fl. Adherence to antiretroviral therapy for human immunodeficiency virus/acquired immune deficiency syndrome among drug users: a systematic review. Addiction. 2008;103(8):1242-57.

19. World Health Organization. HIV/AIDS Treatment and Care - Clinical protocols for the WHO European Region. Copenhagen: WHO Regional Office for Europe; 2007.

20. Hellard M, Sacks-Davis R, Gold J. Hepatitis C treatment for injection drug users: a review of the available evidence. Clin Infect Dis. 2009;49(4):561-73.

21. Stark K, Schreier E, Müller R, Wirth D, Driesel G, Bienzle U. Prevalence and determinants of anti-HCV seropositivity and of HCV genotype among intravenous drug users in Berlin. Scand J Infect Dis. 1995;27(4):331-7.

22. Backmund M, Meyer K, Wächtler M, Eichenlaub D. Hepatitis C virus infection in injection drug users in Bavaria: risk factors for seropositivity. Eur J Epidemiol. 2003;18(6):563-8.

23. Backmund M, Meyer K, Von Zielonka M, Eichenlaub D. Treatment of hepatitis $C$ infection in injection drug users. Hepatology. 2001;34(1):188-93.

24. Reimer J, Schulte B, Castells X, Schafer I, Polywka S, Hedrich D, Wiessing L, Haasen C, Backmund M, Krausz M. Guidelines for the treatment of hepatitis $C$ virus infection in injection drug users: status quo in the European union countries. Clin Infect Dis. 2005;40 Suppl 5:S373-8.

25. Poethko-Muller C, Zimmermann R, Hamouda O, Faber M, Stark K, Ross RS, Thamm M. Epidemiology of hepatitis a, B, and C among adults in Germany: results of the German health interview and examination survey for adults (DEGS1). Bundesgesundheitsblatt Gesundheitsforschung. 2013;56(5-6):707-15.

26. European Monitoring Centre for Drugs and Drug Addiction (EMCDDA), Lisbon; 2015. www.emcdda.europa.eu/data/stats2015\#displayTable:INF-02. Accessed 3 Oct 2015.

27. Robert Koch Institut (RKI). Schätzung der Prävalenz und Inzidenz von HIVInfektionen in Deutschland, stand Ende 2014. EpiBull. 2015;45:475-90.

28. Backmund M. Ansprechbarkeit von Drogengebrauchern über Infektionsrisiken für HIV und HCV. Opioidabhängigkeit und HIV-Infektion. Bundesgesundheitsblatt Gesundheitsforschung. 2007:50(4):471-5.

29. Robert Koch-Institut (RKI). HIV-Infektionen und AIDS-Erkrankungen in Deutschland - Bericht zur Entwicklung im Jahr 2011 aus dem Robert KochInstitut. EpiBull. 2012;2012(28):255-74.

30. Wiessing L, Ferri M, Grady B, Kantzanou M, Sperle I, Cullen KJ, group ED, Hatzakis A, Prins M, Vickerman P, et al. Hepatitis C virus infection epidemiology among people who inject drugs in Europe: a systematic review of data for scaling up treatment and prevention. PLoS One. 2014; 9(7):e103345.

31. Joint United Nations Programme on HIV/AIDS, World Health Organization: Working Group on global HIV/AIDS and STI Surveillance - Guidelines on surveillance among populations most at risk for HIV. Edited by UNAIDS, Geneva; 2011. p. 1-49.

32. Heckathorn DD. Respondent-driven sampling: a new approach to the study of hidden populations. Soc Probl. 1997:44(2):174-99.

33. White RG, Hakim AJ, Salganik MJ, Spiller MW, Johnston LG, Kerr L, Kendall C, Drake A, Wilson D, Orroth K, et al. Strengthening the reporting of observational studies in epidemiology for respondent-driven sampling studies: "STROBE-RDS" statement. J Clin Epidemiol. 2015;68:1463-71.

34. Magnani R, Sabin K, Saidel T, Heckathorn D. Review of sampling hard-to-reach and hidden populations for HIV surveillance. AIDS. 2005;19 Suppl 2:S67-72.

35. Malekinejad M, Johnston LG, Kendall C, Kerr LR, Rifkin MR, Rutherford GW. Using respondent-driven sampling methodology for HIV biological and behavioral surveillance in international settings: a systematic review. AIDS Behav. 2008;12(4 Suppl):S105-30.

36. Heckathorn DD, Jeffri J. Assessing the feasibility of respondent-drivensampling: aging artists in New York City. 2005. p. 1-9.

37. Zimmermann R, Marcus U, Schaffer D, Leicht A, Wenz B, Nielsen S, SantosHovener C, Ross RS, Stambouli O, Ratsch BA, et al. A multicentre serobehavioural survey for hepatitis B and C, HIV and HTLV among people who inject drugs in Germany using respondent driven sampling. BMC Public Health. 2014;14(1):845.

38. European Monitoring Centre for Drugs and Drug Addiction (EMCDDA): An overview of the drug-related infectious diseases (DRID) key indicator. Lisbon: EMCDDA; 2009. http://www.emcdda.europa.eu/system/files/ publications/566/EMCDDA-DRID-overview_127894.pdf.

39. European Monitoring Centre for Drugs and Drug Addiction and Greek REITOX Focal Point, University Mental Health Research Insitute (UMHRI): Protocol for the implementation of EMCDDA key indicator drug related infectios disease. Draft version October 2006. Lisbon: EMCDDA; 2006. http:// www.emcdda.europa.eu/html.cfm/index65537EN.html.

40. Wiessing L, Bravo MJ. DRID guidance module: behavioural indicators for people who inject drugs. Version 10th ed. Lisbon: European Monitoring Centre for Drugs and Drug Addiction (EMCDDA); 2013. p. 67.

41. Ross RS, Stambouli O, Gruner N, Marcus U, Cai W, Zhang W, Zimmermann R, Roggendorf M. Detection of infections with hepatitis B virus, hepatitis C virus, and human immunodeficiency virus by analyses of dried blood spotsperformance characteristics of the ARCHITECT system and two commercial assays for nucleic acid amplification. Virol J. 2013;10(72):72.

42. Deutsche AIDS-Hilfe e.V. Infomappe für die Beratung in Aidshilfen 2013. 2013. p. 60

43. Volz E, Wejnert C, Cameron S, Spiller M, Barash V, Degani I, Heckathorn DD. Respondent-driven sampling analysis tool (RDSAT) version 7.1. Ithaca: Cornell University; 2012.

44. Johnston LG. Behavioural surveillance: introduction to respondent driven sampling (participant manual). in. Atlanta: Centers for Disease Control and Prevention; 2008.

45. Heckathorn DD. Respondent-driven sampling II: deriving valid population estimates from chain-referral samples of hidden populations. Soc Probl. 2002;49(1):11-34.

46. Abdul-Quader AS, Heckathorn DD, McKnight C, Bramson H, Nemeth C, Sabin K, Gallagher K, Des Jarlais DC. Effectiveness of respondent-driven sampling for recruiting drug users in New York City: findings from a pilot study. J Urban Health. 2006;83(3):459-76.

47. Table INF-2. Prevalence of HCV antibody among injecting drug users in the EU, Croatia, Turkey and Norway, 2011 or most recent year available (summary table by country) [http://www.emcdda.europa.eu/ stats13\#display:/stats13/inftab2].

48. Table INF-1. Prevalence of HIV infection among injecting drug users in the EU, Croatia, Turkey and Norway, 2011 or most recent year available (summary table by country) [http://www.emcdda.europa.eu/ stats13\#display:/stats13/inftab1].

49. Levounis P, Galanter M, Dermatis H, Hamowy A, De Leon G. Correlates of HIV transmission risk factors and considerations for interventions in homeless, chemically addicted and mentally ill patients. J Addict Dis. 2002;21(3):61-72.

50. Havens JR, Oser CB, Leukefeld CG. Injection risk behaviors among rural drug users: implications for HIV prevention. AIDS Care. 2011;23(5):638-45. 
51. Die Drogenbeauftragte der Bundesregierung. Drogen- und suchtbericht juli 2014. Berlin: Bundesministerium für Gesundheit; 2014. p. 212

52. Barr AM, Panenka WJ, MacEwan GW, Thornton AE, Lang DJ, Honer WG, Lecomte T. The need for speed: an update on methamphetamine addiction. J Psychiatry Neurosci. 2006:31(5):301-13.

53. Sächsisches Staatsministerium für Soziales. 2. Sächsischer drogen- und suchtbericht, vol. 2. Dresden: Sächsisches Staatsministerium für Soziales Referat Presse- und Öffentlichkeitsarbeit; 2013.

54. European Monitoring Centre for Drugs and Drug Addiction. Exploring methamphetamine trends in Europe, EMCDDA papers, publications office of the European union, Luxembourg. 2014.

55. Heimer R, Eritsyan K, Barbour R, Levina O. Hepatitis C virus seroprevalence among people who inject drugs and factors associated with infection in eight Russian cities. BMC Infect Dis. 2014;14 Suppl 6:S12.

56. Robert Koch-Institut (RKI). Schätzung der prävalenz und inzidenz von HIV-infektionen in Deutschland. EpiBull. 2012;47:466-78.

57. Robert Koch-Institut (RKI). SurvStat@RKI 2.0. Berlin; 2015. https://survstat.rki. de. Accessed 29 July 2015.

58. Robert Koch-Institut (RKI). HIV-Infektionen und AIDS-Erkrankungen in Deutschland -Bericht zur Entwicklung im Jahr 2012 aus dem Robert Koch-Institut. Epid Bull. 2013;24:213-32.

59. Vickerman $P$, Hickman $M$, Judd A. Modelling the impact on hepatitis C transmission of reducing syringe sharing: London case study. Int J Epidemiol. 2007;36(2):396-405.

60. Wiessing L, Likatavicius G, Klempova D, Hedrich D, Nardone A, Griffiths P. Associations between availability and coverage of HIV-prevention measures and subsequent incidence of diagnosed HIV infection among injection drug users. Am J Public Health. 2009;99(6):1049-52.

61. Gibson DR, Flynn NM, Perales D. Effectiveness of syringe exchange programs in reducing HIV risk behavior and HIV seroconversion among injecting drug users. Aids. 2001;15(11):1329-41.

62. Hurley SF, Jolley DJ, Kaldor JM. Effectiveness of needle-exchange programmes for prevention of HIV infection. Lancet. 1997;349(9068):1797-800.

63. Palmateer N, Kimber J, Hickman M, Hutchinson S, Rhodes T, Goldberg D. Evidence for the effectiveness of sterile injecting equipment provision in preventing hepatitis $C$ and human immunodeficiency virus transmission among injecting drug users: a review of reviews. Addiction. 2010;105(5):844-59.

64. Kleiber D, Pant A. HIV - needle-sharing - Sex: eine sozialepidemiologische studie zur analyse der HIV-prävalenz und riskanten verhaltensweisen bei iv-drogenkonsumenten; tabellenband, Nomos verlag-Ges. 1996.

65. Koester S, Glanz J, Baron A. Drug sharing among heroin networks: implications for HIV and hepatitis B and C prevention. AIDS Behav. 2005;9(1):27-39.

66. Bluthenthal RN, Kral AH, Gee L, Erringer EA, Edlin BR. The effect of syringe exchange use on high-risk injection drug users: a cohort study. Aids. 2000; 14(5):605-11.

67. Paintsil E, He H, Peters C, Lindenbach BD, Heimer R. Survival of hepatitis $C$ virus in syringes: implication for transmission among injection drug users. J Infect Dis. 2010;202(7):984-90.

68. Doerrbecker J, Behrendt P, Mateu-Gelabert P, Ciesek S, RiebesehI N, Wilhelm C, Steinmann J, Pietschmann T, Steinmann E. Transmission of hepatitis $C$ virus among people who inject drugs: viral stability and association with drug preparation equipment. J Infect Dis. 2013;207(2):281-7.

69. Eritsyan KU, Levina OS, White E, Smolskaya TT, Heimer R. HIV prevalence and risk behavior among injection drug users and their sex partners in two Russian cities. AIDS Res Hum Retroviruses. 2013;29(4):687-90.

70. Schulte B, Stover H, Thane K, Schreiter C, Gansefort D, Reimer J. Substitution treatment and HCV/HIV-infection in a sample of 31 German prisons for sentenced inmates. Int J Prison Health. 2009;5(1):39-44.

71. Zimmermann R, Radun D. DrogengebraucherInnen, Infektionen und Haft. Ergebnisse der Gefängnisstudie 2006/2007 und vorläufige Ergebnisse der DRUCK-Studie 2011-15 des RKI. In: Stöver HKB, editor. Schriftenreihe "Gesundheitsförderung im Justizvollzug" - "Health promotion in prisons". Volume Band 28th ed. Oldenburg: BIS-Verlag der Carl von Ossietzky Universität Oldenburg; 2014

72. Stover H, Knorr B. HIV, Hepatitis und Haft. HIV and more. 2013;(4):28-35.

73. Pfeiffer-Gerschel T, Kipke I, Flöter S, Jakob L, Hammes D, Raiser P. 2011 National report to the EMCDDA by the REITOX National Focal Point Germany. New developments, trends and in-depth information on selected issues. Munich: Deutsche Beobachtungsstelle für Drogen und Drogensucht DBDD; 2011.

74. Marcus U, Gassowski M, Kruspe M, Drewes J. Recency and frequency of HIV testing among men who have sex with men in Germany and socio-demographic factors associated with testing behaviour. BMC Publ Health. 2015;15.

75. Frost SDW, Brouwer KC, Firestone Cruz MA, Ramos R, Ramos ME, Lozada RM, Magis-Rodriguez C, Strathdee SA. Respondent-driven sampling of injection drug users in two US-Mexico border cities: recruitment dynamics and impact on estimates of HIV and syphilis prevalence. J Urban Health. 2006;83:83-97.

76. Salganik MJ. Commentary: respondent-driven sampling in the real world. Epidemiology. 2012;23(1):148-50

77. McCreesh N, Frost SD, Seeley J, Katongole J, Tarsh MN, Ndunguse R, Jichi F, Lunel NL, Maher D, Johnston LG, et al. Evaluation of respondent-driven sampling. Epidemiology. 2012;23(1):138-47.

78. United Nations Office on Drugs and Crime (UNODC). HIV/AIDS prevention, care, treatment and support in prison settings: a framework for an effective national response. Co-published with the World Health Organization and the Joint United Nations Programme on HIV/AIDS. Vienna: United Nations Office on Drugs and Crime (UNODC); 2006.

\section{Submit your next manuscript to BioMed Central and we will help you at every step:}

- We accept pre-submission inquiries

- Our selector tool helps you to find the most relevant journal

- We provide round the clock customer support

- Convenient online submission

- Thorough peer review

- Inclusion in PubMed and all major indexing services

- Maximum visibility for your research

Submit your manuscript at www.biomedcentral.com/submit

Biomed Central 